$\begin{array}{r}\text { Volume and Issues Obtainable at Center for Sustainability Research and Consultancy } \\ \text { Journal of Business and Social Review in Emerging Economies } \\ \text { ISSN: 2519-089X (E): 2519-0326 } \\ \text { Volume 6: No. 4, December 2020 } \\ \text { CSRC } \\ \text { Journal homepage: www.publishing.globalcsrc.org/jbsee } \\ \hline\end{array}$

\title{
Corporate Social Responsibility for Competitive Advantage in Project Management: Evidence from Multinational Fast-Food Companies in Pakistan
}

\author{
${ }^{1}$ Mariam Sohail, ${ }^{2}$ Shahid Iqbal, ${ }^{3}$ Waheed Asghar, ${ }^{4}$ Syed Arslan Haider \\ ${ }^{1} \mathrm{PhD}$ Scholar, Department of Management,Superior University, Lahore Campus, Pakistan, \\ Mariam_sohail10@yahoo.com \\ ${ }^{2}$ Assistant Professor, Management Studies Department,Bahria University, Islamabad Campus, Pakistan, \\ siqbal.buic@bahria.edu.pk \\ ${ }^{3}$ Director in Technical Education and Vocational Training Authority, Government of the Punjab, Lahore, \\ Pakistan,waheedasgharpk@gamil.com; director.at@tevta.gop.pk \\ ${ }^{4} \mathrm{PhD}$ Scholar, Department of Management, Sunway University Business School (SUBS), \\ Sunway University, Selangor Darul Ehsan, Malaysi, haidershah24@ gmail.com
}

\begin{tabular}{|c|c|}
\hline \multicolumn{2}{|c|}{ ARTICLE DETAILS } \\
\hline \multicolumn{2}{|l|}{ History } \\
\hline \multicolumn{2}{|c|}{$\begin{array}{l}\text { Revised format: November } \\
2020\end{array}$} \\
\hline \multicolumn{2}{|c|}{$\begin{array}{l}\text { Available Online: December } \\
2020\end{array}$} \\
\hline \multicolumn{2}{|l|}{ Keywords } \\
\hline Corporate & social \\
\hline responsibility; & Competitive \\
\hline advantage; & Multinational \\
\hline companies; & Competitors; \\
\hline Project & Management; \\
\hline Stakehol & \\
\hline
\end{tabular}

JEL Classification

M10, M14
ABSTRACT

The aim of current articleis to examine the relationship between corporate social responsibility and competitive advantage in Project Management. This research used "Quantitative Methods" in which data was collected from five multinational fast-food companies of Pakistan by use of Likert Scale questionnaire. A sample of 80 persons was selected by using random sampling technique who are engaged in the selection and execution of corporate social responsibility activities. Data was statistically analyzed using the SPSS software version 20.Findings indicate that most of the multinational fast-food companies of Pakistan are engaged in corporate social responsibility practices. So, there is significant positive relationship between corporate social responsibility and competitive advantage.

(C) 2020 Center for Sustainability Research and Consultancy Pakistan under a Creative Commons Attribution-NonCommercial-ShareAlike 4.0

Corresponding author's email address: siqbal.buic@bahria.edu.pk

Recommended citation: Sohail, M., Iqbal, S., Asghar, W. \& Haider, S. A. (2020). Corporate Social Responsibility for Competitive Advantage in Project Management: Evidence from Multinational FastFood Companies in Pakistan. Journal of Business and Social Review in Emerging Economies, 6(4), $1277-1288$

\section{Introduction}

Nyuur, Ofori and Amponsah (2019) states that organizations now-a-days are concerned for stakeholders and social issues and want to become good corporate citizens. Ağan et al. (2016) discussed that the honor of an organization depends on the directing values of an organization. Lee et al. (2016) said that organizations have become superior economic institutions of the world from respective ambiguity over the last one and a half century. Prior studies also indicated that in modern business world organizations are interested in ethics and values are considered an important element of success (Solomon, 2016; Farooq et al., 2020). Moreover, organizational values are continually fluctuating because of various elements. 
Corporate social responsibility (CSR) contains the actions by which minimum responsibilities of an organization to the stakeholders are raised (Alshbili \&Elamer, 2020). Social responsibility means constructive contribution of an organization to the society.CSR is the involvement of an organization in the actions by using its resources that would assist the society (Noor et al., 2020). CSR helps in building a constructive and long-term relations with the society. If an organization is working for the welfare of the society i.e. giving donations, they will have to pay less tax as donations for these activities are exempt from tax and this decreases the burden of tax on an organization. Although, competitive advantage (CA) is the organizational ability to consume its rare resources and skills in the selection and execution of schemes (Shaukat, Qiu \& Trojanowski, 2016). CA supports organizations to yield higher profits as compared to their competitors, increase the market share and lead in the industry.The CSR is a valuable approach which helps the organizations in getting a competitive advantage over its rivals and researchers are interested in this topic (Farooq et al., 2020, Noor et al., 2020).

Therefore, the purpose of this study is to explore the CSR activities of the multinational fast-food companies in Pakistan and to investigate the relationship between corporate social responsibility and competitive advantage. The previous studies in this field had determined the role of corporate social responsibility in determination of competitive advantage for multinational fast-food organization. But this report will cover the future concerns of fast-food companies to use the extent of corporate social responsibility to build strategies for Pakistan. It is important for the fast-food organization, so to drive the ideas and assist in selection of CSR activities that construct strategies either for short term or for long term.

\section{Literature Review}

\subsection{Corporate Social Responsibility}

The concept corporate social responsibility (CSR) is an important ethical issue which organizations should consider while making decisions (Jesús Herrera Madue, 2016). A business term CSR evolved in the last years of twentieth century when a large number of organizations diverted their attention to the effect of organizational actions on environment and society (Ahmad, Shafique \& Jamal, 2020). Though, CSR is gaining importance now-a-days. Essentially, CSR is the responsibility of an organization to its society, especially the responsibility to its stakeholders and those who affect the organizational decisions and practices (Mahmood \&Alsayegh, 2020).CSR is the activities of an organization in addition to its core expertise that are operated to provide benefit to the society. CSR is associated with the actions in which minimum responsibilities of an organization to the stakeholders exceeds which are described by rules (Arslanb \& Demirtaşc, 2016). It is valuable for the organizations to work for the welfare of society by using its resources. The society is an essential component of the organization which provides human resources, consumers, raw materials and investors (Schulz \& Flanigan, 2016). Organizations give extensive response of goodwill to the society which is tangible and measurable(Bakhsh, Mahmood \& Mahmood, 2019).

Organizations should examine their CSR practices by using the similar plans that direct their important business decisions. Organizations will determine that CSR is not only a cost, restriction, or a charitable act but can also lead to innovation, opportunity and competitive (Odipo\& Njeru, 2016).CSR is the motive to support and obligate organizations to accept more accountability for their conduct (Advantage, 2020). Organizations take their responsibilities of providing employment, eradicating favoritism and preventing pollution (Joscha Nollet, 2015). Furthermore, CSR is a concept in which organization takes the responsibility of helping the society and the monetary concerns of its investors (Wójcik, 2016).Recent study by Waple, \& Brachle (2020) specified that CSR contains four components: philanthropic, legal, social and economic responsibility shown in pyramid form where philanthropic is at the top and it follows legal, social and economic responsibility directed towards the bottom of an organization. Economic responsibility is central obligation of an organization regarding organizational profits by satisfying the wants and requirements of customers (Bakhsh et al., 2019). Legal responsibility 
is the obligation of an organization to follow law. An organization that performs the social responsibility practices, we will state that it follows the principles related to the business ethics. Philanthropic responsibility considers that organizations are good corporate citizens and add to the resources of society. CSR includes two important elements: transparency and responsibility. No doubt the basic purpose of organizations is to perform financially and to earn profits but they are also responsible to the stakeholders.

Additionally, the subject of discussion in the CSR field is that an organization survives with the aim of earning profit or to seek other activities. According to the stakeholders approach the main purpose of the organization is to work for the welfare of their stakeholders (Zhang et al., 2020). An organization should perform the functions that are related with profit and also be the good corporate citizen. Organizations should keep in mind that how their functions and polices will influence the employees, environment, community and society (Lu et al., 2020).

\subsection{Competitive Advantage}

Competitive advantage (CA) is the organization's ability to obtain expertise in order to operate in a better way as compared to its competitors and to supply best quality goods and services than their rivals (Saeidi et al., 2015).CA is the picture in which an organization generates greater economic value than its competitors (Zhao et al., 2019). Economic value is the difference between full economic cost of goods or services and advantage perceived by a buyer of organizational goods or services. There will be the competitive equality when an organization generates the same economic value as its competitors or there will be competitive disadvantage when an organization generates less economic value than its competitors (Nyuur et al., 2019).

According to (Opilo, Mulili \& Kimani., 2018) CA is a valuable asset for an organization as it guarantees the progress of an organization even if the performance of economy is poor. If an organization has selected its own market segment and is superior to its rivals because of its cost, it will be a market leader and customers will prefer this brand.CA is that how organizations achieve their targets while competing with other rivals (Su et al., 2016). To achieve their goals organizations must outperform than their competitors in the industry. In this case organizations could not fulfill the wants of their customers efficiently and they could charge high prices to increase their profits. Similarly, if an organization is cost-effective, it would charge low price to its customers which will lead to increase in revenues (Aksak et al., 2016). Organizations not only get competitive advantage over its rivals but also they sustain it for a long time. According to the (Lee et al., 2016), that it's the competitive advantage because of which customers prefer the products of a company over its competitors. Organizations can get sustainable CA by using generic strategies such as cost leadership, differentiation and focus (Yin \& Jamali, 2016).

Multinational fast-food organizations have various important channels to achieve competitive advantage. (Wickert et al.,2016), described that an organization uses cost leadership strategy in which it produces the goods at low cost to achieve more profits than its competitors. Organizations can also use differentiation strategy in which they offer unique products or services to customers than their competitors. In focus strategy, organizations concentrate on a narrow segment of the market and in this segment cost leadership or differentiation is achieved and finally this market segment will be less appealing for the rivals. Organizations can also get competitive advantage by using their resources. Some of the resources can generate advantage for an organization as favorable organizational prestige, brand equity, organizational ability to consume resources efficiently like delivery of the products is speedy than rivals.

\subsection{Corporate Social Responsibility and Competitive Advantage}

Various studies have been conducted on CSR (JoschaNollet, 2015; Alshbili et al., 2020).Prior studies examined the relationship between CSR and competitive advantage and stated that every organization can recognize specific social issues and organizations can have better solution of these issues by which 
they will gain CA (Lu et al., 2020). Aksak et al. (2016)studied the relationship between CSR and corporate strategies in the stock exchange companies and reported that CSR plays an important in building the image of organizations and concluded that CSR related concerns should be given more importance. Advantage (2020) studied that CSR is a tool to manage stakeholders in large companies. This study concluded that while formulating strategies involvement of CSR is important to make unique products and brand whereas actions done for CSR fulfill the criteria of the cost benefit analysis. Waples \&Brachle (2020) defined that organizations have an important role in providing benefit to its society.

There is an association between CSR and competitive advantage (Ağan et al., 2016). According to (Wójcik, 2016), companies can get a chance of competitive advantage with the help of CSR. (Lu et al., 2020) clarified that firms perform social responsibility activities because they perceive that it will help them in getting competitive advantage. Firms are the part of society; they are not separate from the society in which they exist and perform their operations. Now-a-days firms are motivated to perform the CSR activities (Solomon, 2016). So, themanagers give more importance to CSR like other investment decisions. Wickert et al. (2016) also illustrated there are two different CSR cases, first is normative case which state that organizations should perform social responsibility actions because it is ethically good and second is business case which state that organizations should be asked that how they can make economic progress by paying concentration on social responsibility actions. To perform CSR activities, companies have to make short term investment but the benefits associated with CSR are long-term.

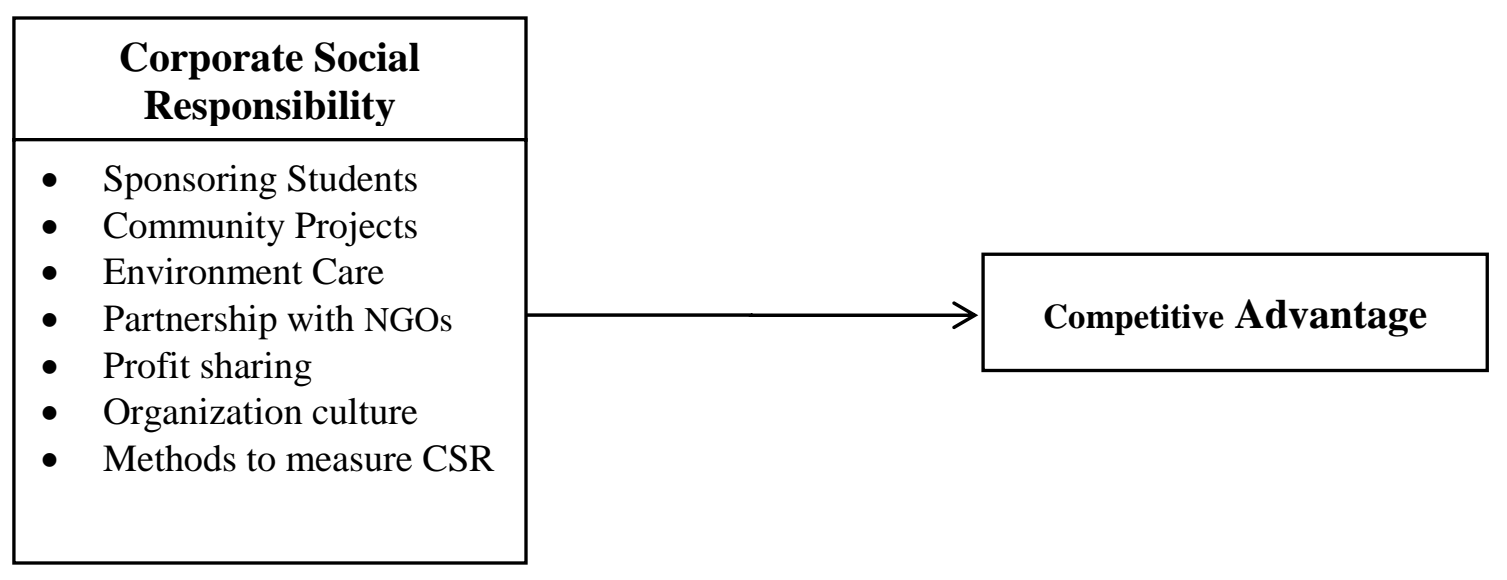

Figure 1: Research model

\section{Methodology}

\subsection{Research Design}

In this research paper, "quantitative research methods" is used to analyze the data (Park \& Park, 2016). The primary data is used in this research which has been collected from Five-point Likert scale questionnaire which is adopted from (Mbugua, 2012). The questionnaire is composed of 3 main parts demonstrating:

- Demographics

- CSR Practices

- Competitive Advantage

The simple random sampling technique has been selected owing to a number of reasons including expedited data collection due to time restraint and availability of reliable data in order to gather data and analyze it quickly. Due to COVID-19, respondents are not willing to provide data in face to face meeting therefore data was collected through online. An aggregate of 120 surveys were conveyed and 80 participants returned the questionnaire. The response rate was quite encouraging in such difficult COVID-19 time period, yielding a response rate of $66.66 \%$. Because of time limitation data has been collected within three months (i.e. February 2020 to April 2020) for this study. Population for this 
research consists of managers, project managers working in five multinational fast-food organizations. The SPSS version 26.0 software was used for analyzing the responses received from the respondents to confirm the data reliability and further analysis (Pallant, 2020).

Out of these respondents, $61 \%$ were male and $39 \%$ were female, as the presence of women in construction projects in Pakistan is quite low. The majority of the sample fell within the ages of 21-30 years old. With respect to the educational level, large numbers of respondents are Master degree holders. Also, the respondents of current study had majority Forty-six $(58 \%)$ employees have work experience of 1-5 years, twenty-nine (36\%) employees have work experience of 6-10 years and five (6\%) employees have work experience of 11-15 years. All these work experiences of employees were in their current organizations.

Table 1: Descriptive Analysis

\begin{tabular}{cccc}
\hline & & Frequency & Percent \\
\hline Gender & Male & 49 & 61 \\
Age & Female & 31 & 39 \\
& $21-30$ & 39 & 49 \\
\multirow{5}{*}{ Qualification } & $31-40$ & 24 & 30 \\
& $41-50$ & 17 & 21 \\
& Intermediate & 5 & 6 \\
Experience & Bachelor & 19 & 24 \\
& Master & 56 & 70 \\
& $1-5$ years & 46 & 58 \\
& 6-10 years & 29 & 36 \\
& $11-15$ years & 5 & 6 \\
\hline
\end{tabular}

\subsection{Corporate Social Responsibility Practices}

$8 \%$ employees responded that their organizations sponsor to the brilliant and needy students to a very great extent, $25 \%$ employees responded that their organizations sponsor students to a great extent and $59 \%$ employees responded that their organizations sponsor students to a moderate extent.

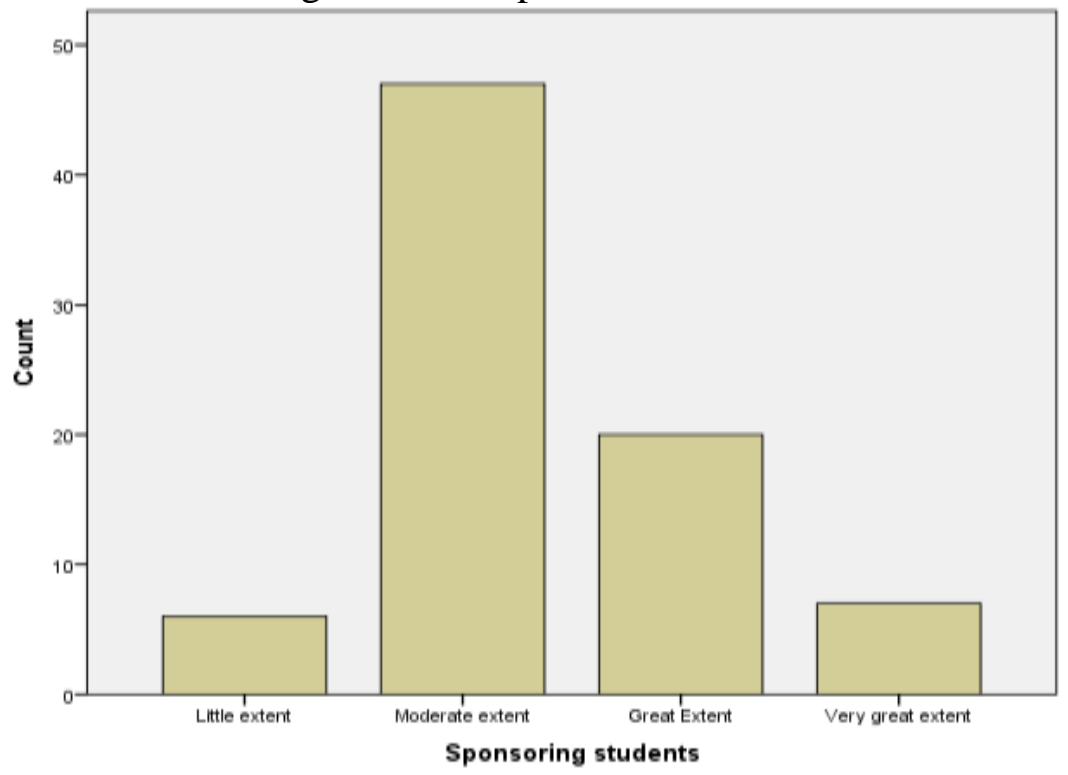

Figure 2: Sponsoring Students

$44 \%$ employees responded that their organizations are involved in community projects to a very great extent, 52\%employees responded that their organizations are involved in community projects to a great extent and $4 \%$ employees responded that their organizations are connected with community projects to a moderate extent. 


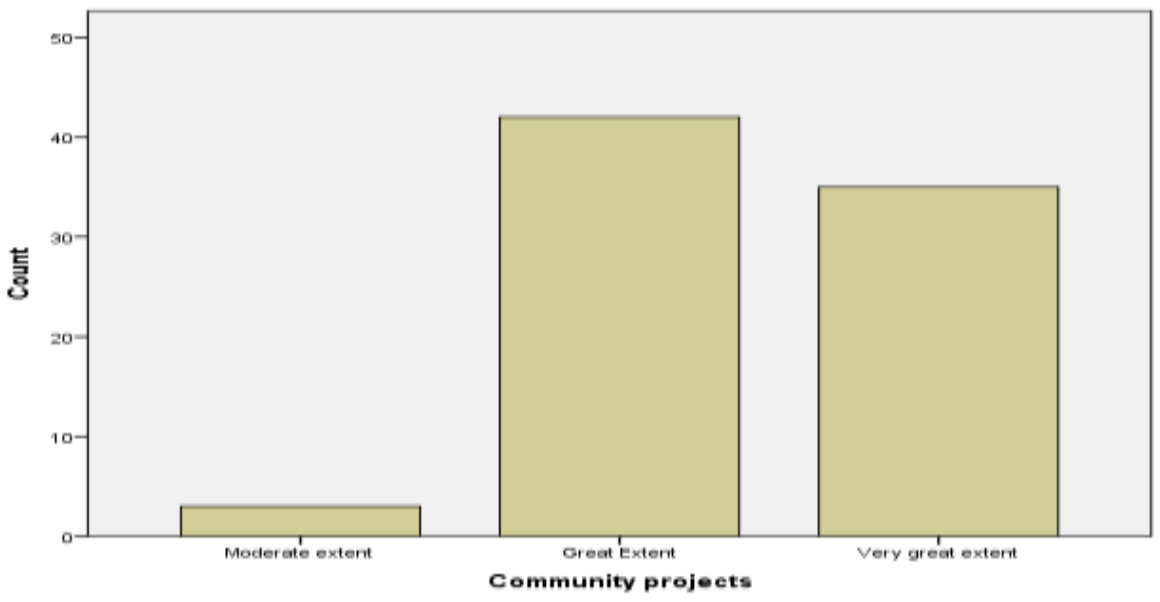

Figure 3: Community Projects

$46 \%$ employees responded that their organizations do environment care to a very great extent because their production processes are environment friendly, 51\% employees responded that their organizations do environment care to a great extent and $3 \%$ employees responded that their organizations do environment care to a moderate extent.

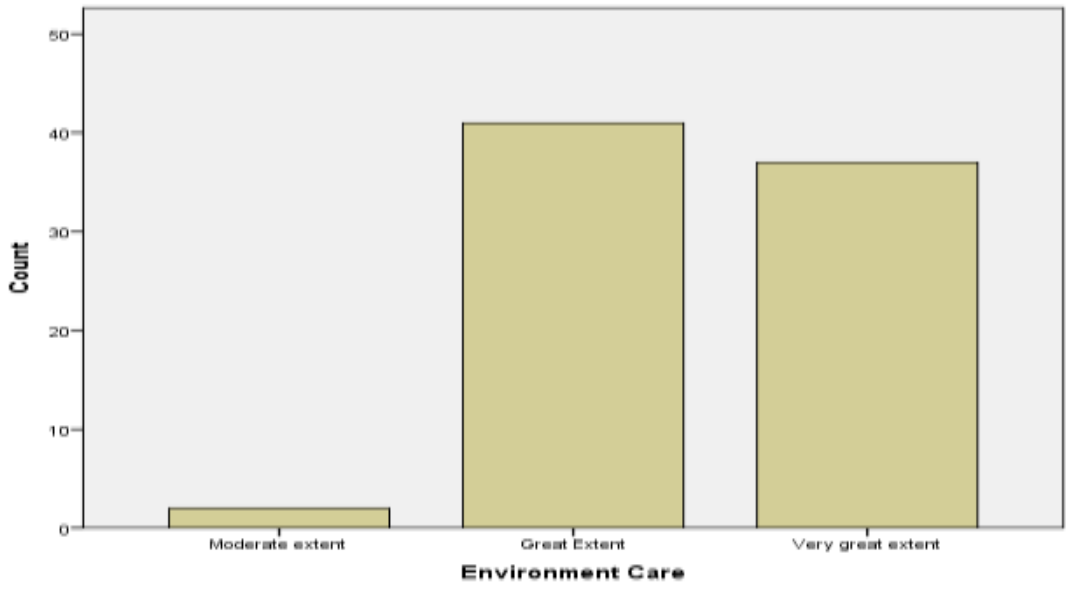

Figure4: Environment Care

$56 \%$ employees responded that their organizations have partnership with NGOs in different activities to a very great extent, $34 \%$ employees responded that their organizations have partnership with NGOs to a great extent and 6\%employees responded that their organizations have partnership with NGOs to a moderate extent.

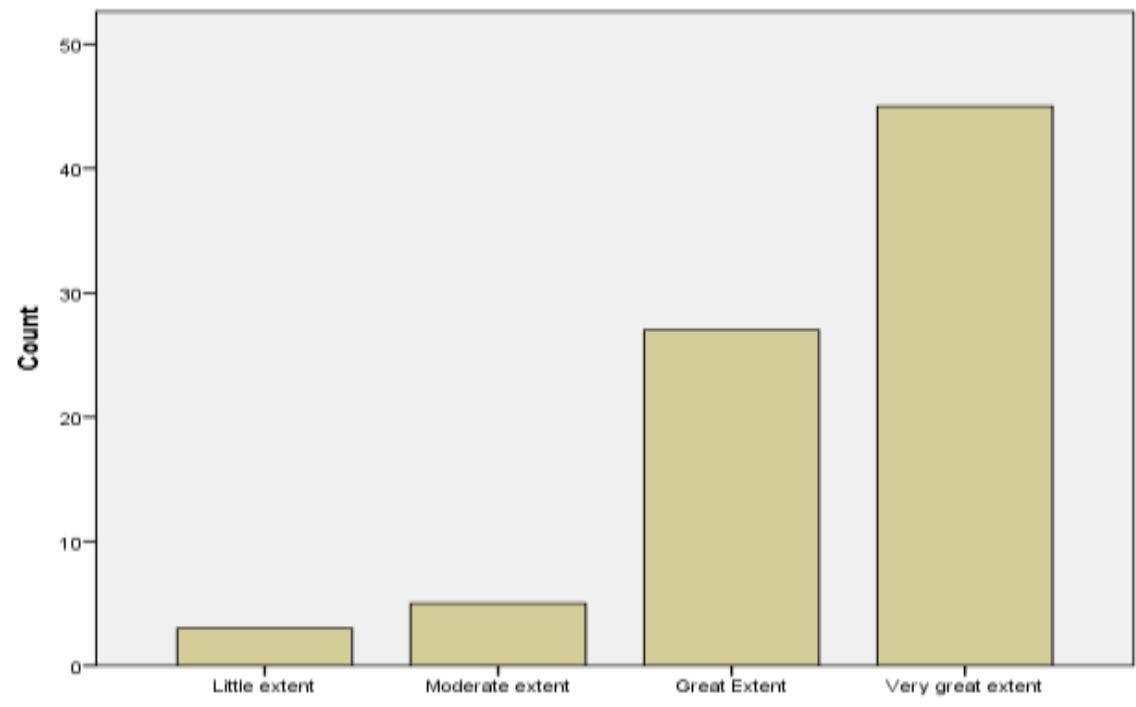

Partnership with NGOs 


\section{Figure5: Partnership with NGOs}

$43 \%$ employees responded that their organizations share profits with needy members of the society to a very great extent, $41 \%$ employees responded that their organizations share profits with needy members of the society to a great extent and $14 \%$ employees responded that their organizations share profits with needy members of the society to a moderate extent.

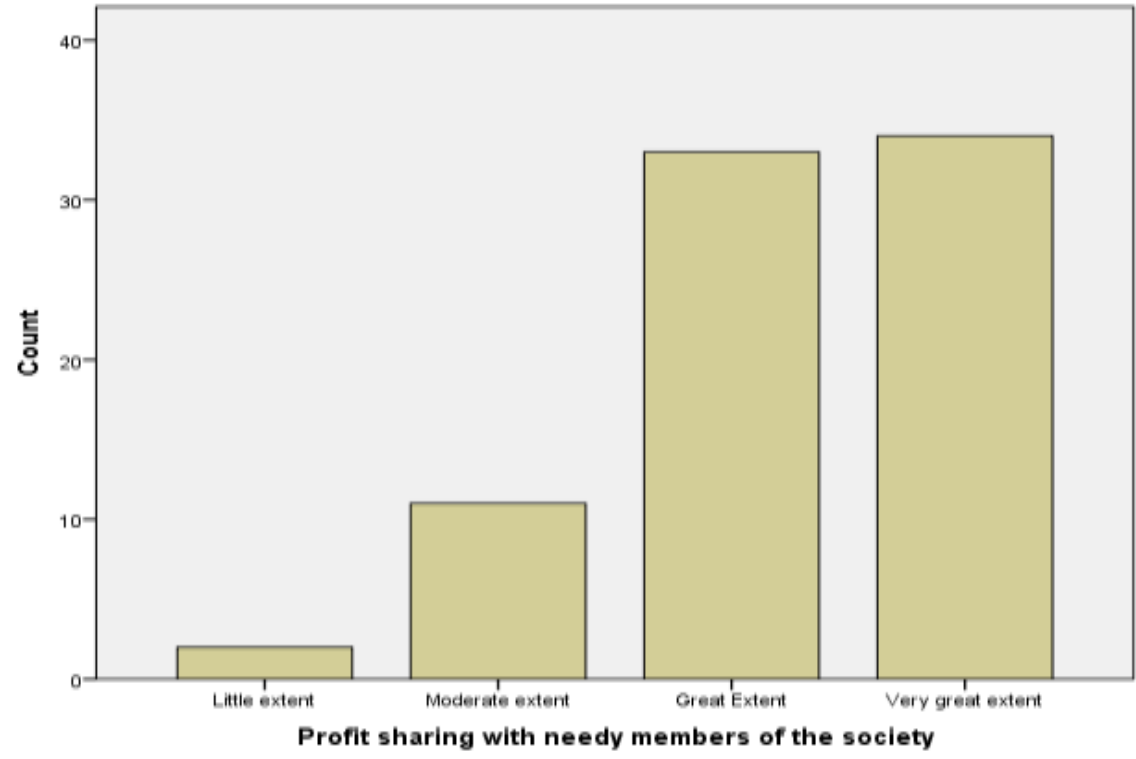

Figure6: Profit sharing with needy members of the society

$37 \%$ employees responded that their organization culture is supported by HR policy of CSR to a very great extent; $50 \%$ employees responded that their organization culture is supported by HR policy of CSR to a great extent and $11 \%$ employees responded that their organization culture is supported by HR policy of CSR to a moderate extent.

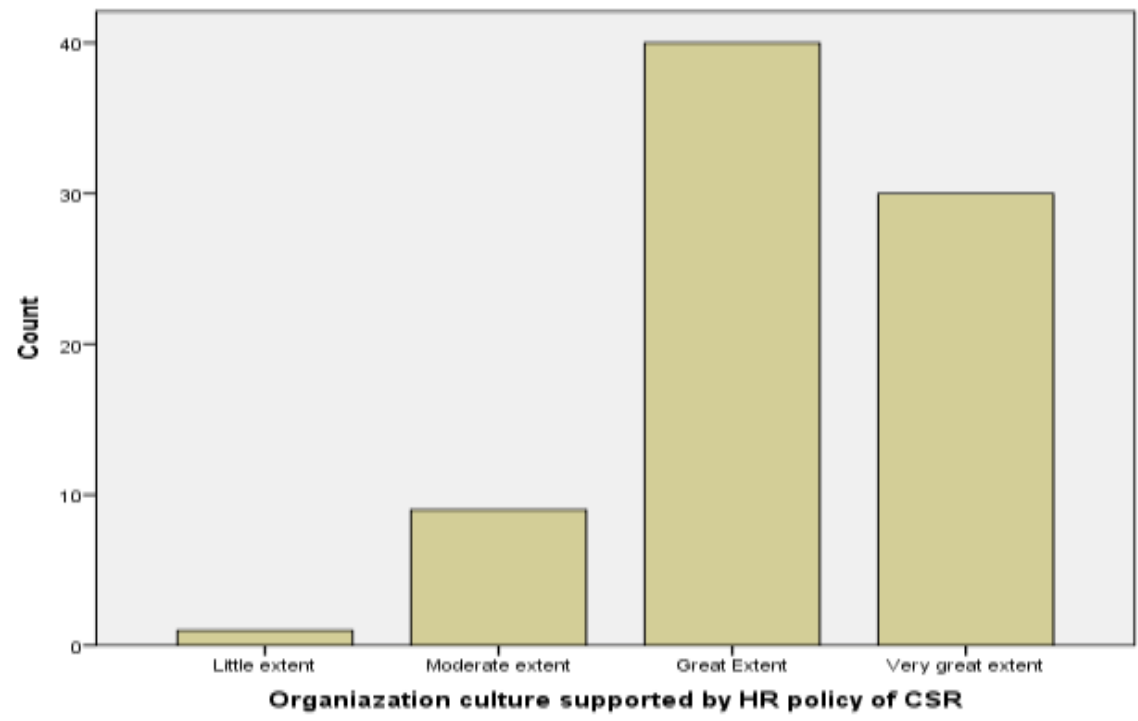

Figure7: Organization culture supported by HR policy of CSR 
$26 \%$ employees responded that their organizations have methods to measure CSR obtaining desired results to a very great extent, $50 \%$ employees responded that their organization have methods to measure CSR obtaining desired results to a great extent and $24 \%$ employees responded that their organization have methods to measure CSR obtaining desired results to a moderate extent.

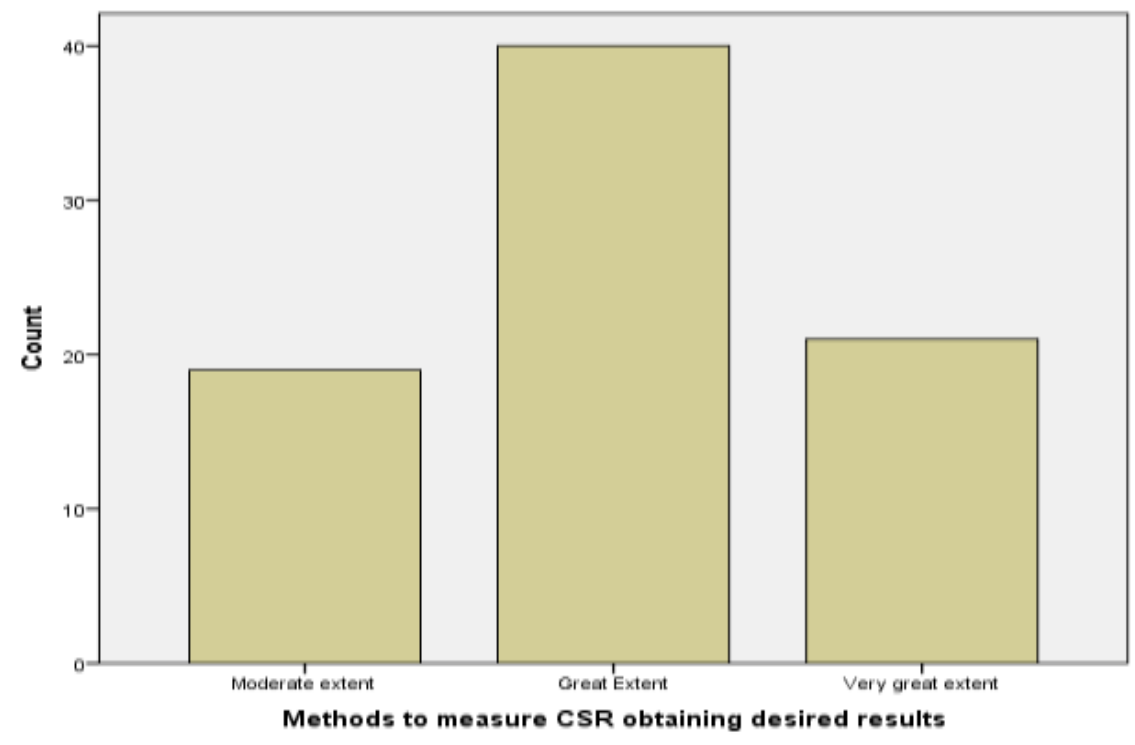

Figure 8: Methods to measure CSR obtaining desired results

The findings indicate that multinational fast-food companies of Pakistan are actively engaged in the corporate social responsibility practices.

\subsection{Relationship between CSR and Competitive Advantage}

Pearson correlation coefficient test was appliedtofind the relationship between corporate social relationship and competitive advantage. This statistical test measures whether there is any association between CSR and competitive advantage.

Table 1 represents the correlations between corporate social responsibility and competitive advantage. There is significant positive relationship between CSR and competitive advantage $(r=0.605, p=.000)$. Thus, we can say that the multinational companies which are actively engaged in CSR will get the competitive advantage over its rivals.

Table 2: Correlation Analysis

\begin{tabular}{lcc}
\hline \multicolumn{3}{c}{ Corporate Social Responsibility } \\
\hline & Pearson Correlation & $.605^{* *}$ \\
Competitive Advantage & Sig. (2-tailed) & .000 \\
**. Correlation is significant at the 0.01 level (2-tailed). & 80 \\
\hline
\end{tabular}

\section{Conclusion}

The findings of the paper indicate that most of the multinational fast-food companies in Pakistan are engaged in corporate social responsibility practices. They are voluntarily engaged in these activities. Pearson correlation coefficient was used to find the association between CSR and competitive advantage which represent that there is significant positive relationship between CSR and competitive advantage. 
Multinationals which are involved in CSR practices will have more competitive advantage as compared to the companies which are not involved in CSR practices.

\section{Limitations of the Study}

There were limited resources available for this research such as shortage of finance and time. Small sample size is also the limitation of this study. Only quantitative method of research was used in which questionnaires were distributed among the employees of five multinational fast-food companies and results were statistically analyzed but there is also need of qualitative research to get more detailed information of the topic.

\section{Future Research Suggestions}

Further study is needed to confirm the relationship between corporate social responsibility and competitive advantage and to overcome the limitations of current research. Future research can be done by conducting interviews of human resource managers of the multinational fast food companies to get their perceptions and views about CSR and competitive advantage. Industries other than fast food can be studied to find out the strength of relationship between CSR and competitive advantage in each industry.

\section{References}

Advantage, C. (2020). Corporate Social Responsibility. CSR and Socially Responsible Investing Strategies in Transitioning and Emerging Economies, 65.

Ağan, Y., Kuzey, C., Acar, M. F., \&Açıkgöz, A. (2016). The relationships between corporate social responsibility, environmental supplier development, and firm performance. Journal of Cleaner Production, 112, 1872-1881.

Ahmad, S., Shafique, O., \& Jamal, W. N. (2020). Impact of Perceived Corporate Social Responsibility on Banks' Financial Performance and the Mediating Role of Employees' Satisfaction and Loyalty in Pakistan. Journal of Accounting and Finance in Emerging Economies, 6(3), 765-774.

Aksak, E. O., Ferguson, M. A., \&Duman, S. A. (2016). Corporate social responsibility and CSR fit as predictors of corporate reputation: A global perspective. Public Relations Review, 42(1), 79-81.

Alshbili, I., \&Elamer, A. A. (2020). The influence of institutional context on corporate social responsibility disclosure: a case of a developing country. Journal of Sustainable Finance \& Investment, 10(3), 269-293.

Arslanb, A. A. A. A., \&Demirtaşc, Ö. (2016). A strategic influence of corporate social responsibility on meaningful work and organizational identification, via perceptions of ethical leadership. Procedia-Social and Behavioral Sciences, 235, 259-268.

Bakhsh, A., Mahmood, Z., \& Mahmood, A. B. (2019). An International Investigation of the Institutional Factors Driving Sustainability Assurance. Journal of Business and Social Review in Emerging Economies, 5(2), 367-378.

Farooq, Q., Liu, X., Fu, P., \& Hao, Y. (2020). Volunteering sustainability: An advancement in corporate social responsibility conceptualization. Corporate Social Responsibility and Environmental Management. Retrieved from: https://doi.org/10.1002/csr.1893

Jesús Herrera Madue, M. L. (2016). Relationship between corporate social responsibility and competitive performance in Spanish SMEs: Empirical evidence from a stakeholders' perspective. BRQ Business Research Quarterly, 55-72.

JoschaNollet, G. F. (2015). Corporate Social Responsibility and Financial Performance: A non-linear and disaggregated approach. Business and Society Review, 237-256.

Lee, E. M., Lee, H. J., Pae, J. H., \& Park, S. Y. (2016). The important role of corporate social responsibility capabilities in improving sustainable competitive advantage. Social Responsibility Journal. 12 (4), 642-653. Retrieved from: https://doi.org/10.1108/SRJ-11-2015-0163

Lu, J., Ren, L., Zhang, C., Rong, D., Ahmed, R. R., \&Streimikis, J. (2020). Modified Carroll's pyramid of corporate social responsibility to enhance organizational performance of SMEs industry. Journal of Cleaner Production, 271, 122456.

Mahmood, Z., \&Alsayegh, M. F. (2020). The Governance of Corporate Sustainability in the Middle 
East: Preliminary Insights. Journal of Business and Social Review in Emerging Economies, 6(2), 715-731.

Mbugua, T. W. (2012). Corporate social responsibility and competitive advantage in multinational food and beverage companies in Kenya (Doctoral dissertation). Retrieved from: http://erepository.uonbi.ac.ke:8080/xmlui/handle/123456789/10696

Nie, N. H., Bent, D. H., \& Hull, C. H. (1975). SPSS: Statistical package for the social sciences, 227.

Noor, A., Farooq, M., Yamin, M., \& Khan, S. N. (2020). Corporate Social Responsibility and its Nexus with Firm Performance and Institutional Ownership: An Emerging Market Context. Journal of Business and Social Review in Emerging Economies, 6(2), 845-858.

Nyuur, R. B., Ofori, D. F., \&Amponsah, M. M. (2019). Corporate social responsibility and competitive advantage: A developing country perspective. Thunderbird International Business Review, 61(4), 551-564.

Odipo, B. A., \& Njeru, A. W. (2016). To examine the influence of market place as a factor of corporate social responsibility on competitive advantage within pharmaceutical companies in Kenya. International Journal of Academic Research in Business and Social Sciences, 6(7), 130-141.

Opilo, P. M., Mulili, B., \& Kimani, S. (2018). Corporate social responsibility and competitive advantage perspectives from employees of Safaricom Kenya Limited. Journal of Marketing and Communication, 1(2), 1-21.

Pallant, J. (2020). SPSS survival manual: A step by step guide to data analysis using IBM SPSS. Routledge.

Park, J., \& Park, M. (2016). Qualitative versus quantitative research methods: Discovery or justification?.Journal of Marketing Thought, 3(1), 1-8.

Saeidi, S. P., Sofian, S., Saeidi, P., Saeidi, S. P., \&Saaeidi, S. A. (2015). How does corporate social responsibility contribute to firm financial performance? The mediating role of competitive advantage, reputation, and customer satisfaction. Journal of business research, 68(2), 341-350.

Scherer, C. W. (2016). Walking and Talking Corporate Social Responsibility: Implications of Firm Size and Organizational Cost. Journal of Management Sciences.

Schulz, S. A., \& Flanigan, R. L. (2016). Developing competitive advantage using the triple bottom line: A conceptual framework. Journal of Business \& Industrial Marketing. 31 (4), 449-458. Retrieved from: https://doi.org/10.1108/JBIM-08-2014-0150

Shaukat, A., Qiu, Y., \&Trojanowski, G. (2016). Board attributes, corporate social responsibility strategy, and corporate environmental and social performance. Journal of Business Ethics, 135(3), 569585.

Solomon, G. T. (2016). External Determinants and Financial Outcomes of an Eco-friendly Orientation in Smaller Manufacturing Firms. Journal of Small Business Management, 5-25.

Su, W., Peng, M. W., Tan, W., \& Cheung, Y. L. (2016). The signaling effect of corporate social responsibility in emerging economies. Journal of business Ethics, 134(3), 479-491.

Waples, C. J., \&Brachle, B. J. (2020). Recruiting millennials: Exploring the impact of CSR involvement and pay signaling on organizational attractiveness. Corporate Social Responsibility and Environmental Management, 27(2), 870-880.

Wickert, C., Scherer, A. G., \& Spence, L. J. (2016). Walking and talking corporate social responsibility: Implications of firm size and organizational cost. Journal of Management Studies, 53(7), 11691196.

Wójcik, P. (2016). How creating shared value differs from corporate social responsibility. Journal of Management and Business Administration. Central Europe, 24(2), 32-55.

Yin, J., \& Jamali, D. (2016). Strategic corporate social responsibility of multinational companies subsidiaries in emerging markets: Evidence from China. Long Range Planning, 49(5), 541-558.

Zhang, Q., Cao, M., Zhang, F., Liu, J., \& Li, X. (2020). Effects of corporate social responsibility on customer satisfaction and organizational attractiveness: A signaling perspective. Business Ethics: A European Review, 29(1), 20-34.

Zhao, Z., Meng, F., He, Y., \& Gu, Z. (2019). The influence of corporate social responsibility on competitive advantage with multiple mediations from social capital and dynamic capabilities. 
Sustainability, 11(1), 218.

\section{Appendix: \\ 1) Questionnaire}

\begin{tabular}{|l|}
\hline \multicolumn{2}{|l|}{ Section A: General Information } \\
\hline $1 . \quad$ Gender \\
\hline Male ( ) Female ( ) \\
\hline $2 . \quad$ What is your age group? \\
\hline $21-30($ ) $31-40($ ) $41-50($ ) $50+($ ) \\
\hline $3 . \quad$ What is your level of education? \\
\hline Intermediate ( )Bachelor( ) Master ( ) \\
\hline $4 . \quad$ How many years of work experience do you have in this organization? \\
Section B: Corporate Social Responsibilities Practices \\
To what extent does your company is engaged in each of the following Corporate Responsibility \\
practices
\end{tabular}

1. Sponsoring brilliant but needy students.

Not at all Little extent Moderate extent Great Extent Very great extent

$\begin{array}{lllll}1 & 2 & 3 & 4 & 5\end{array}$

2. Community projects such as drilling bore holes for the semi-arid and arid areas.

Not at all Little extent Moderate extent Great Extent Very great extent

$\begin{array}{lllll}1 & 2 & 3 & 4 & 5\end{array}$

3. Care for the environment through use of environment friendly production processes.

Not at all Little extent Moderate extent Great Extent Very great extent

$\begin{array}{lllll}1 & 2 & 3 & 4 & 5\end{array}$

4. Partner with Non-Governmental Organizations' in various activities.

Not at all Little extent Moderate extent Great Extent Very great extent

$\begin{array}{lllll}1 & 2 & 3 & 4 & 5\end{array}$

5. Share profits with under privileged members of the society through initiatives that explicitly state this.

Not at all Little extent Moderate extent Great Extent Very great extent

$\begin{array}{llllll}1 & 2 & 3 & 4 & 5\end{array}$

6. Have an organization culture reinforced through the Human resource policy of fostering

CSR in the day to day running of the organization.

Not at all Little extent Moderate extent Great Extent Very great extent

$\begin{array}{lllll}1 & 2 & 3 & 4 & 5\end{array}$

7. Have a think tank within the organizations strategy to deliberately choose and execute CSR activities.

Not at all Little extent Moderate extent Great Extent Very great extent

$\begin{array}{lllll}1 & 2 & 3 & 4 & 5\end{array}$

8. Have a budgetary allocation in its financial planning cycle for achieving CSR activities

Not at all Little extent Moderate extent Great Extent Very great extent

$\begin{array}{lllll}1 & 2 & 3 & 4 & 5\end{array}$

9. Projects aimed at uplifting the orphans, sick and the homeless.

Not at all Little extent Moderate extent Great Extent Very great extent

$\begin{array}{lllll}1 & 2 & 3 & 4 & 5\end{array}$

10. Economically empowering community through establishing products that allow businesses to thrive.

Not at all Little extent Moderate extent Great Extent Very great extent

$\begin{array}{lllll}1 & 2 & 3 & 4 & 5\end{array}$

11. Mechanisms of measuring effectiveness of CSR achieving desired outcome e.g. benchmarking, balance score card.

Not at all Little extent Moderate extent Great Extent Very great extent 


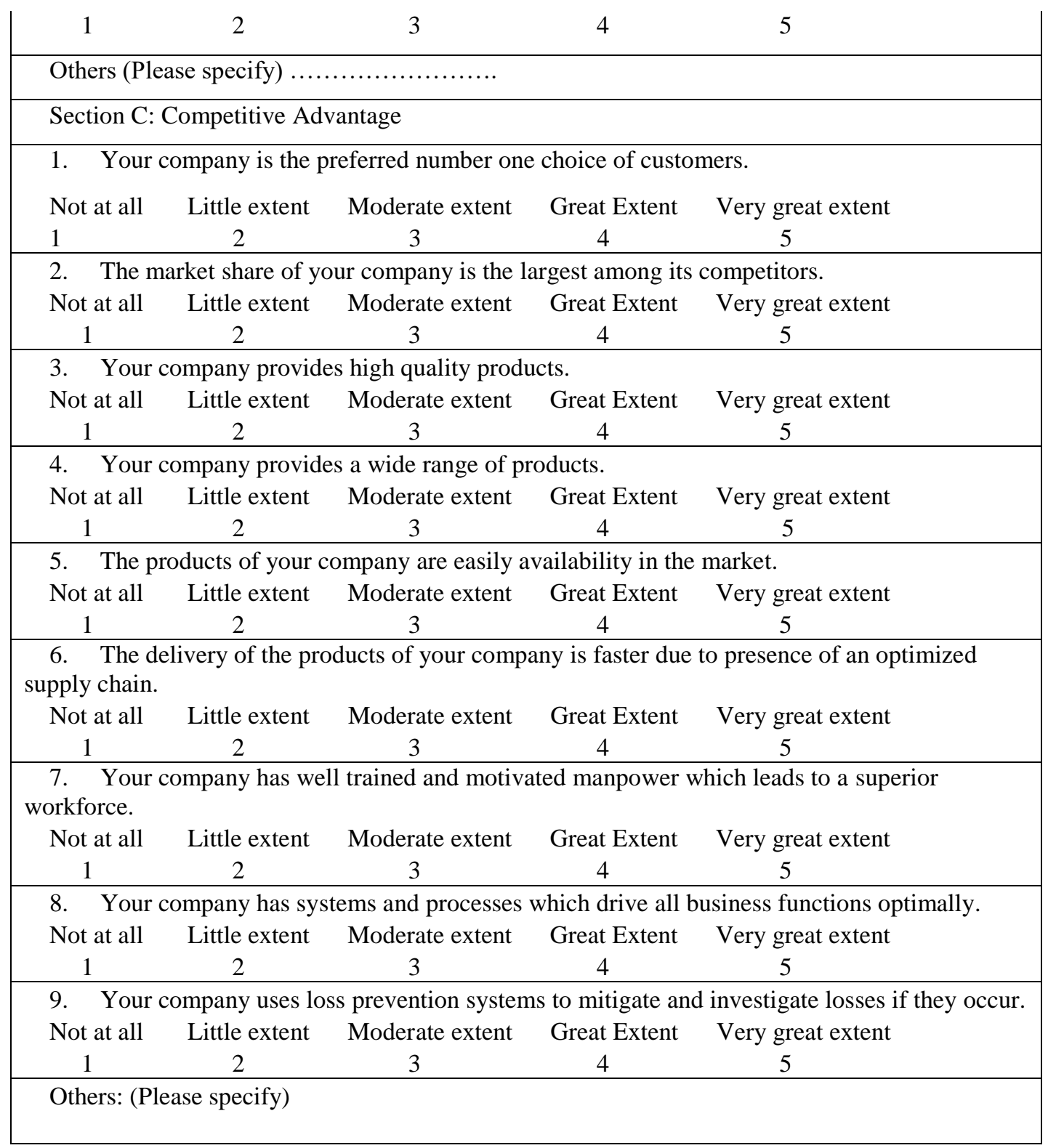

Thank you for your co-operation. 